2015-05-28

Detergent less ultrasound-assisted extraction of trace elements from edible oils using lipase as an extractant

\title{
Kara, D
}

http://hdl.handle.net/10026.1/12083

10.1016/j.talanta.2015.05.056

TALANTA

All content in PEARL is protected by copyright law. Author manuscripts are made available in accordance with publisher policies. Please cite only the published version using the details provided on the item record or document. In the absence of an open licence (e.g. Creative Commons), permissions for further reuse of content should be sought from the publisher or author. 
Disclaimer: This is a pre-publication version. Readers are recommended to consult the full published version for accuracy and citation. Published in Talanta, 144, (2015) 219-225, doi:

10.1016/j.talanta.2015.05.056

\title{
Detergentless ultrasound-assisted extraction of trace elements
}

\section{from edible oils using lipase as an extractant}

\author{
Derya Kara $^{\mathrm{a}^{*}}$, Andrew Fisher ${ }^{\mathrm{b}}$ and Steve Hill ${ }^{\mathrm{b}}$ \\ ${ }^{a}$ Department of Chemistry, Art and Science Faculty, Balikesir University, 10100 Balikesir, Turkey \\ ${ }^{b}$ School of Geography, Earth and Environmental Sciences, University of Plymouth, Drake Circus, \\ Plymouth, Devon PLA 8AA, UK
}

NOTICE: this is the author's version of a work that was accepted for publication in Talanta.

Changes resulting from the publishing process, such as peer review, editing, corrections, structural formatting, and other quality control mechanisms may not be reflected in this document. Changes may have been made to this work since it was submitted for publication. A definitive version was subsequently published in Talanta [VOL 144] DOI 10.1016/j.talanta.2015.05.056

\begin{abstract}
A new method for the extraction and preconcentration of trace elements $(\mathrm{Al}, \mathrm{Ba}, \mathrm{Cd}, \mathrm{Cu}, \mathrm{Fe}$, $\mathrm{Mn}, \mathrm{Mo}, \mathrm{Ni}, \mathrm{Ti}, \mathrm{V}$ and $\mathrm{Zn}$ ) from edible oils by producing detergentless micro-emulsions via an ultrasound-assisted extraction using a water phase containing Lipase at $\mathrm{pH} 3$ as an extractant was developed. The trace elements in the water phase post-extraction were determined against matrix matched standards using ICP-MS. In the first step of the work, the parameters that affect extraction, such as $\mathrm{pH}$, the volume of $1 \%$ lipase in the water phase and the ultrasonic and centrifugation times were optimized. Under the optimal conditions, the detection limits $\left(\mu \mathrm{g} \mathrm{kg}^{-1}\right)$ were $0.46,0.03,0.007$, 0.028, 0.67, 0.038, 0.022, 0.14, 0.17, 0.05 and 0.07 for $\mathrm{Al}, \mathrm{Ba}, \mathrm{Cd}, \mathrm{Cu}, \mathrm{Fe}, \mathrm{Mn}, \mathrm{Mo}, \mathrm{Ni}, \mathrm{Ti}, \mathrm{V}$ and $\mathrm{Zn}$ respectively for edible oils (3Sb/m). A certified reference material (EnviroMAT HU-1 Used oil) was analysed to check the accuracy of the developed method. Results obtained were in agreement
\end{abstract}


with certified values with a t-test showing that no significant differences at the $95 \%$ confidence levels were found. The proposed method was applied to different edible oils such as sunflower oil, rapeseed oil, olive oil and salmon oil.

Key words: Edible oil, Ultrasound-assisted emulsification, extraction, detergentless micro-emulsions, Lipase, Inductively Coupled Plasma-Mass Spectrometry

Corresponding Author : Tel : + 902666121000 Fax: + 902666121215

e-mail address: $\underline{\text { dkara@ } @ \text { balikesir.edu.tr }}$

\section{Introduction}

Edible vegetable oils such as sunflower oil, rapeseed oil or olive oil are used in food for cooking. Others, e.g. fish oils are used as dietary supplements. The human body uses oils and fats in the diet as an energy source, as structural components and to make powerful biological regulators. They also play an important role in metabolic reactions in the human organism [1]. The metal contents in edible oils are important because of toxicological as well as their nutritional viewpoints. Trace metals present in oils may be of natural origin or present due to processing procedures or storage [2-3]. The concentrations of trace metals in edible oils may directly affect their quality. The presence of trace metals such as $\mathrm{Cu}, \mathrm{Fe}, \mathrm{Mn}, \mathrm{Ni}$ and $\mathrm{Zn}$ are known to have deleterious effects on the oxidative stability of edible seed oils and this can affect the quality of these products $[4,5]$. Other elements such as $\mathrm{As}, \mathrm{Cd}, \mathrm{Cr}, \mathrm{Hg}$ and $\mathrm{Pb}$ are very important on account of their toxicity and metabolic role and must be strictly controlled $[3,5]$. The determination of metals in edible oils has been a difficult analytical problem because of the high organic content of the oil matrix [5] which makes the direct determination of the metals in these samples almost impossible. Different sample pretreatment methods (such as digestion, emulsification, extraction and dilution) have been developed and reported in the literature. Some of these different sample preparation methods; e.g. dry and wet ashing or different extraction methods, have been reviewed by Lepri et al. (2011) [5] 
and Bagdat Yasar et al. (2012) [6]. Microwave digestion systems [7-11], open vessel and closed vessel digestion in a steel bomb [11] and dry ashing [12] have been used to dissolve edible oils for elemental analyses. In sample dilution methods, edible oils have been diluted with an appropriate solvent (xylene, kerosene, toluene, propan-1-ol, etc.) [13]. Extraction induced by emulsion breaking (EIEB) involved producing water oil emulsions using surfactants such as Triton X-100 followed by heating [14] or centrifugation [15] to separate the acid phase from the surfactant and oil phase. Direct analysis of detergent emulsions of edible oils with surfactants has also been achieved enabling the determination of their trace elemental content $[4,16]$. Another technique that has been used to produce emulsions is mixing the oil sample with an alcohol such as propan-1-ol without using any surface active materials [2-3, 17-18]. An ultrasound-assisted extraction technique without any surfactant or organic solvent was developed to extract copper and lead from palm oil samples [19]. Bakircioglu et al.[20] compared several sample preparation methods including extraction induced by emulsion breaking, ultrasonic extraction and wet digestion for the determination of metals in edible oil samples in Turkey prior to ICP-OES determination. The EIEB procedure was found to be fast, reliable, simple, and excellent in comparison with the other procedures studied.

Enzymes are biocatalysts that can also be used for digestion of biological substrates prior to analysis. Different enzymes have been involved in sample pre-treatment for the determination of total-elemental content and also for speciation analysis [21]. Enzymatic hydrolysis procedures are a group of sample pretreatments that hydrolyze biomolecules, mainly proteins. The enzymatic hydrolysis breaks down certain bonds of these biomolecules under certain environmental conditions such as $\mathrm{pH}$, temperature, and ionic strength. After enzymatic hydrolysis action, the metal or organometallic species are released from the biological material into solution and can be measured using either atomic spectrometric or chromatographic techniques [22]. It should be noted, however, that the efficiency of analyte release can be variable and depends on sample type, enzyme used and even on the species present. The behaviour of lipase as a ligand has been investigated by Schwedt et al. [23]. The metal speciation analyses for iron and manganese in foodstuffs were studied using the 
protein, pectin, and lipid splitting enzymes pepsin, pectinase, papain, bromelain, and lipase using a stepwise extraction procedure. This paper discussed the different enzymatic extraction efficiencies with respect to the composition of foodstuffs as a precursor to a biochemical, i.e. enzymological, method for metal-speciation analysis of foodstuffs. An ultrasound bath-assisted enzymatic hydrolysis procedure as a sample pretreatment for the multielement determination in mussels prior to ICP-OES detection was performed by Pena-Fartal et al. [22]. A mixture of protease XIV- lipase was used by Mellano et al. [24] for the extraction of seleno-methyl-selenocysteine (SeMetSeCys) and selenomethionine (SeMet) in biota samples prior to analysis using gas chromatography-mass spectrometry (GC-MS).

In this work, a lipase enzyme was proposed as an extracting reagent for $\mathrm{Al}, \mathrm{Ba}, \mathrm{Cd}, \mathrm{Cu}, \mathrm{Fe}, \mathrm{Mn}$, Mo, Ni, Ti, V and Zn from edible oils by ultrasound assisted emulsification without using a detergent prior to ICP-MS detection. After optimization of the experimental variables and determination of analytical features, the procedure was applied to the determination of these elements in edible oil samples. The developed method was validated using a certified reference material.

\section{Experimental}

An ICP-MS instrument (X Series 2, Thermo Scientific, Hemel Hempstead, UK) was used for the determination of the analytes $\mathrm{Al}, \mathrm{Ba}, \mathrm{Cd}, \mathrm{Cu}, \mathrm{Fe}, \mathrm{Mn}, \mathrm{Mo}, \mathrm{Ni}, \mathrm{Ti}, \mathrm{V}$ and $\mathrm{Zn}$. The isotopes measured were $27,137,111,65,56,55,95,60,47,51$ and 66 for $\mathrm{Al}, \mathrm{Ba}, \mathrm{Cd}, \mathrm{Cu}, \mathrm{Fe}, \mathrm{Mn}, \mathrm{Mo}, \mathrm{Ni}$, $\mathrm{Ti}, \mathrm{V}$ and $\mathrm{Zn}$ respectively. The operating conditions for the ICP-MS instrument were: forward power $1.40 \mathrm{~kW}$, coolant gas flow rate $12 \mathrm{~L} \mathrm{~min}^{-1}$, auxiliary gas flow rate $0.8 \mathrm{~L} \mathrm{~min}^{-1}$; nebulizer gas flow rate $0.82 \mathrm{~L} \mathrm{~min}^{-1}$, a dwell time per isotope of $10 \mathrm{~ms}$ and with 50 sweeps. To overcome polyatomic interferences, a collision cell gas comprising $7 \%$ hydrogen in helium at a flow rate of

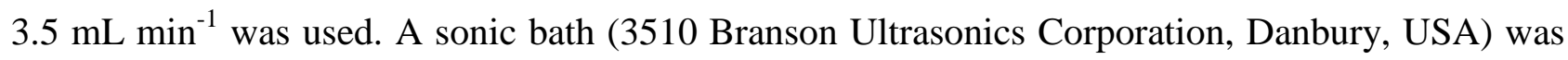


used to sonicate the samples and a centrifuge (Centaur 2 MSE, London, UK) was utilized for the centrifugation.

\subsection{Reagents and Solutions}

All chemicals were of analytical reagent grade unless otherwise stated and all dilutions were made with high purity water $(18.2 \mathrm{M} \Omega \mathrm{cm})$ obtained from a Prima reverse osmosis and Maxima water system (Elga, Buckinghamshire, UK). Potassium chloride, hydrochloric acid, potassium hydrogen phthalate, sodium hydroxide, potassium dihydrogen phosphate, and lipase (Type VII (E.C. 3.1.1.3) from Candida cylindracea) were purchased from Sigma-Aldrich (Dorset, UK). The sample and standard solutions for ultrasonic extraction and centrifugation of edible oils were prepared in Corning $^{\circledR} 50$ and $15 \mathrm{~mL}$ polypropylene centrifuge tubes. Stock standard solutions of individual metals (1000 or 10,000 mg L ${ }^{-1}$ ) were supplied by Fisher Scientific (Loughborough, UK). Buffer solutions, (0.2 $\mathrm{M}$ at $\mathrm{pH} 1.0$ and $\mathrm{pH} 2.0)$, were prepared using pure potassium chloride and hydrochloric acid. Buffer solutions (0.2 M) of $\mathrm{pH} \mathrm{3,4}$ and 5 were prepared using potassium hydrogen phthalate, hydrochloric acid and sodium hydroxide. Potassium dihydrogen phosphate and sodium hydroxide were used to prepare $0.2 \mathrm{M}$ buffer solutions of $\mathrm{pH} 6,7$ and 8 . The reference material EnviroMAT HU-1 Used oil, (SCP Science, Canada, obtained from $\mathrm{QM}_{\mathrm{X}}$ Laboratories, Essex, UK) was used to prove the accuracy of the developed procedure. $1 \%$ Lipase solution adjusted to $\mathrm{pH} 3$ was prepared freshly for each experiment.

\subsection{General Procedure}

The extraction of metals from edible oils was performed by a novel approach by mixing $3 \mathrm{~g}$ of edible oil and $1 \mathrm{~mL}$ of $1 \%$ Lipase solution adjusted to $\mathrm{pH} 3$ in a $15 \mathrm{~mL}$ polypropylene centrifuge tube. After the tubes were capped, they were shaken vigorously for a few seconds and then vortex mixed. They were then sonicated for 10 mins in an ultrasonic bath to produce water-oil emulsions. The Lipase extracts were then separated by centrifugation at $3000 \mathrm{rpm}$ for $20 \mathrm{mins}$. The emulsions 
were separated completely after centrifugation and therefore the upper oil phase in each of the tubes was decanted and discarded. The aqueous Lipase phase containing the metal extracts from each of the edible oils was subjected to ICP-MS analysis to determine the concentrations of the metal ions. All optimization experiments were performed with replicate analyses of sunflower oil and sunflower oil containing $0.1 \%(w / w)$ of the Certified Reference Oil Material. The recovery results were calculated by taking the difference between the analytes' concentrations in the sunflower oil and the reference material spiked sunflower oil and then multiplying by the dilution factor. Calibration standards were prepared daily using serial dilutions of the stock solutions (1000 or

$10,000 \mathrm{mg} \mathrm{L}^{-1}$ ) of the metal ions in $1 \%$ Lipase solution prepared in $\mathrm{pH} 3.0$ buffer. A mixture of In and Ir was added to all calibration standards, blanks and samples as an internal standard to give a final concentration of $10 \mu \mathrm{g} / \mathrm{L}$ each.

\subsection{Sample analysis}

Four different edible oil samples (sunflower oil, olive oil, rapeseed oil and salmon oil) were bought from markets in Plymouth, UK. The procedure described above was applied to $3.0 \mathrm{~g}$ of these samples and a certified reference material (EnviroMAT HU-1 Used oil). The certified reference oil material contains very high concentrations of trace metals and was therefore diluted in sunflower oil to give a final proportion of $0.1 \%$.

\section{Results and Discussion}

A detergentless ultrasonic assisted extraction method has been proposed for the determination of trace elements in edible oils using lipase solution as an extraction reagent. Analytical parameters including $\mathrm{pH}$ of the aqueous phase, the concentration of lipase solution and the ultrasonic extraction and centrifugation times were optimized in order to obtain highly sensitive, accurate and reproducible results. A Univariate optimization procedure was undertaken to determine the 
optimum value for each of the parameters, i.e. one parameter was varied while the others were kept constant. All the experiments were performed in triplicate. Optimal conditions were defined as those at which the maximum recovery for trace elements was obtained.

\subsection{Optimization of Extraction Variables}

The first parameter to be optimized was the $\mathrm{pH}$ of the extraction medium. The $\mathrm{pH}$ of the $1 \%$ lipase solutions was adjusted over the range 1 to 8 using different buffer solutions. The proposed method was applied in triplicate at each $\mathrm{pH}$ using the constant ultrasonic and centrifugation times of 20 mins and with separate aliquots of $3 \mathrm{~g}$ of sunflower oil and sunflower oil containing $0.1 \%(\mathrm{w} / \mathrm{w}$ ) of the Certified Reference Oil Material. The highest ultrasonic assisted extraction efficiency for all of the trace elements was observed over a $\mathrm{pH}$ range between 3 and 4 (Figure 1). The extraction efficiencies of $\mathrm{Al}, \mathrm{Ba}, \mathrm{Cd}, \mathrm{Cu}, \mathrm{Fe}, \mathrm{Mn}$ and $\mathrm{Ni}$ decreased significantly at $\mathrm{pH}$ values above 5 . The recovery values were less than $50 \%$ for $\mathrm{Cr}, \mathrm{Ag}, \mathrm{Sn}$ and $\mathrm{Pb}$ at all $\mathrm{pH}$ values and so these elements were not included in subsequent experiments. Therefore, $\mathrm{pH} 3.0$, at which all the remaining trace elements had maximum extraction yield, was selected as the optimum for all further experiments.

The influence of the volume of $1 \%$ lipase solution was investigated over the range 0 to $2 \mathrm{~mL}$ at $\mathrm{pH} 3.0$ while the ultrasonic and centrifugation times were kept constant at $20 \mathrm{~min}$. The extraction efficiencies of the trace elements increased gradually with an increase in the volume of $1 \%$ lipase solution up to $1 \mathrm{~mL}$ and then stayed stable at the higher volumes. Therefore, $1 \mathrm{~mL}$ of the $1 \%$ lipase solution at $\mathrm{pH} 3.0$ was selected as the optimum value (Figure 2). Lipase solutions of concentration higher than $1 \%$ were tested. However, the very high dissolved solids loading of the resulting solutions led to gradual blocking of the ICP-MS torch. This led to significant instrumental sensitivity drift and necessitated cleaning of the torch at regular intervals. Consequently, lipase concentrations of $1 \%$ were used throughout.

The proposed ultrasonic assisted extraction method was applied over time periods ranging from 5 to 30 mins while the centrifugation time was kept constant at 20 mins. These experiments 
were performed in triplicate. The ultrasonic extraction step could be performed for fifty of the 15 $\mathrm{mL}$ tubes simultaneously. The results of these experiments indicate that an ultrasonic extraction time of 10 mins is sufficient to supply the mixing and homogenising of the edible oil and lipase phases since the extraction efficiency for all trace metals did not increase further if longer ultrasonic times were used. It was therefore decided that an ultrasonic extraction time of 10 mins was optimal for transfer of the trace elements from the oil phase to the extraction phase. This was used for all further experiments.

Finally, the centrifugation time was optimized over the range of 5 to 30 mins while the other parameters were kept constant at their optimal values. The centrifugation step could be performed for sixteen of the $15 \mathrm{~mL}$ tubes simultaneously. The results show that a 10 min centrifugation time was sufficient to separate the lipase phase from the edible oil phase adequately for all of the analytes except for Mo. The extraction of the Mo was complete after 20 mins centrifugation. Therefore, a centrifugation time of 20 minutes was optimal for the transfer of all of the analytes from the oil phase to the extraction phase and was used for all subsequent experiments.

\subsection{Preconcentration Experiments}

Since most edible oils contain trace elements at very low concentrations, the possibility of adapting the proposed method to obtain a preconcentration of the trace metal ions was investigated. Different amounts of edible oil within the range of 3-10 g were used. Amounts of edible oil greater than $10 \mathrm{~g}$ were not tested because of the difficulty of obtaining emulsions in $1.0 \mathrm{~mL}$ of $1 \%$ Lipase solution. Increasing the volume of the lipase solution would increase transfer efficiency but would also decrease the preconcentration factors. However, using up to $10 \mathrm{~g}$ of oil and $1 \mathrm{~mL}$ of $1 \%$ lipase solution, the recoveries of all elements studied in this work did not change significantly. It was therefore concluded that the proposed method could be applied to preconcentrate these elements from edible oils. 


\subsection{Analytical Characteristics}

The linearity and the detection limit for each analyte were determined to evaluate the performance of the method. Calibration equations were obtained using calibration solutions for each element over the concentration ranges $5-50 \mu \mathrm{g} \mathrm{L} \mathrm{L}^{-1}$ prepared from the multi-element solutions that were prepared daily in $1 \%$ lipase solution prepared in $\mathrm{pH} 3.0$ buffer. The internal standard mixture of In and Ir was added to each calibration standard, blank and sample to give a final concentrations of 10 $\mu \mathrm{g} \mathrm{L}^{-1}$. The limits of detection in the edible oils $\left(\mu \mathrm{g} \mathrm{kg}^{-1}\right)$ were $0.46,0.03,0.007,0.028,0.67,0.038$, 0.022, $0.14,0.17,0.05$ and 0.07 for $\mathrm{Al}, \mathrm{Ba}, \mathrm{Cd}, \mathrm{Cu}, \mathrm{Fe}, \mathrm{Mn}, \mathrm{Mo}, \mathrm{Ni}, \mathrm{Ti}, \mathrm{V}$ and $\mathrm{Zn}$ respectively $(3 \mathrm{Sb} / \mathrm{m})$. These values were calculated using the proposed method taking into account $3 \mathrm{~g}$ of edible oil extracted into $1 \mathrm{~mL}$ of $1 \%$ lipase solution. As discussed previously, the proposed method yielded very good recovery values and a preconcentration factor of 10 for $10 \mathrm{~g}$ of the sample solution could be obtained. Therefore, under these conditions, the detection limits obtained would be 3.33 fold lower than the LOD values quoted above.

\subsection{Analysis of Edible oils}

The proposed detergentless ultrasound-assisted extraction method was applied for the determination of $\mathrm{Al}, \mathrm{Ba}, \mathrm{Cd}, \mathrm{Cu}, \mathrm{Fe}, \mathrm{Mn}, \mathrm{Mo}, \mathrm{Ni}, \mathrm{Ti}, \mathrm{V}$ and $\mathrm{Zn}$ in different edible oils as well as to a certified reference oil sample (EnviroMAT HU-1 used oil). Since the certified material contained very high concentrations of these trace elements, it was diluted in sunflower oil to give a proportion of $0.1 \%$. A comparison method described by Cassella et al. [8] was also performed to validate the proposed method. The results obtained from analysis of the CRM using the proposed method, the comparison method and certified results for the certified material are given in Table 1. The concentrations for trace elements obtained by the proposed method were in the range of the confidence interval (confidence level of 95\%) of the certified material. Although the consensus and confidence interval values have been given in the certificate of the reference material, the $t$ test has not been applied to these results because the standard deviation values are not given. 
The $F$ test is a test designed to indicate whether there is a significant difference between two methods based on their standard deviations. If the experimental $F$ value $\left(F=s_{1}{ }^{2} / s_{2}{ }^{2}\right.$ where $\left.s_{1}{ }^{2}>s_{2}{ }^{2}\right)$ exceeds a critical $F$ value at a selected confidence level, then there is a significant difference between the variances of the two methods. The experimental $\mathrm{F}$ values have been calculated to compare the precision of the two sets of data obtained from the proposed method and the comparison method in Table 1 (for the CRM) and Table 2 (for the edible oils). Only three experimental F values (Fe and Mn for Rape seed oil and Al for Sunflower oil in Table 2) exceeds the critical F value given as 19 for 2 degrees of freedom for both of the methods. These results indicate that the t-test is applicable for comparison of the proposed method with the comparison method. This enables us to investigate whether or not there is a significant difference between the mean concentrations found using the proposed and the comparison methods.

Therefore, individual sample $t$ tests was performed for each of the analytes in the certified material to investigate whether or not there is a significant difference between the mean concentrations found using the proposed method and the comparison method. The experimental $t$ values for the determinations of $\mathrm{Al}, \mathrm{Ba}, \mathrm{Cd}, \mathrm{Cu}, \mathrm{Fe}, \mathrm{Mn}, \mathrm{Mo}, \mathrm{Ni}, \mathrm{Ti}, \mathrm{V}$ and $\mathrm{Zn}$ in the certified oil reference material obtained using the equation $t_{d}=\frac{\left|\bar{x}_{1}-\bar{x}_{2}\right|}{S_{b} \sqrt{\frac{N_{1}+N_{2}}{N_{1} \cdot N_{2}}}}$

(where $\bar{x}_{1}$ and $\bar{x}_{2}$ represent experimental means and $\mathrm{s}_{1}$ and $\mathrm{s}_{2}$ represent experimental standard deviations obtained by the proposed method and a comparison method successively) are smaller than the critical value of $t$ for 4 degrees of freedom which is 2.78 at the $95 \%$ confidence interval except for Fe and Mo. This indicates that there is no evidence of systematic error in the proposed method; confirming that the results obtained by the proposed method were in good agreement with the certified values and with the results obtained using the comparison method. It was concluded that they therefore demonstrated good accuracy. 
Since the analysis of the certified material demonstrated good accuracy, the proposed method was then applied to the determination of these elements in several types of edible oils including rapeseed oil, salmon oil, sunflower oil and olive oil. Rape seed oil, sunflower oil and olive oil samples were also analysed using the comparison method. The results are given in Table 2. The $\mathrm{t}$ test given above was also applied to these results. Most of the results obtained by the proposed method and the comparison method were in good agreement at the confidence level of $95 \%$.

\subsection{Comparison of the proposed method with other methods in the literature}

Even though dry ashing and wet digestion methods have also been used to decompose edible oils prior to the determination of trace elements, a comparison of the proposed method with other methods given in Table 3 focuses on similar methods reported in the literature. Sample dilution methods have some advantages in that they are simple and fast and allow the direct determination of the elements in the edible oils. However, they can cause interferences or physical problems with the instrumental process because of the organic solvents used. In addition, the use of diluting solvents erodes the limits of detection for trace elements [5]. In the direct measurement of the detergent emulsions method, Triton X-100 emulsions of soy, olive oil and sunflower oil were very unstable and started to separate in less than $3 \mathrm{~min}$, even though several different ratios of sample to surfactant were tested $[3,16]$. Margarine and butter samples were previously solubilized in xylene. However, their emulsions in Triton X-100 were not formed [3]. Alcoholic dispersions (detergentless emulsions) of oil and fat samples gives higher limits of detection because of the dilution factor, with sample comprising only between $1 \%$ and $10 \%$, by weight of the material introduced to the detector [3]. An ultrasound-assisted extraction technique has the disadvantages of obtaining high limits of detection because of the very low volume of the edible oil $(100 \mu \mathrm{L})$ being extracted into $2 \mathrm{~mL}$ of the extraction solution and very long ultrasonic extraction time (60 min). In addition, an extra 20 min boiling step was required to decompose the excess hydrogen peroxide [19]. Most of the 
methods in the literature discussed above include the use of hazardous organic solvents, concentrated acids and surfactants and may yield higher limits of detection because of dilution of the sample.

The proposed detergentless ultrasound-assisted extraction method using lipase as an extractant has important advantages over these other methods. These benefits include: 1) Toxic organic solvents or detergents are not used, 2) it is simple and low cost, 3) very low limits of detection are obtained because there is no need to dilute the sample. The LOD values may even be improved by a factor of three by preconcentration to enhance the sensitivity 4) it has a rapid analysis time totalling $30 \mathrm{~min}$ for ultrasonic extraction and centrifugation. However, 50 samples can be extracted simultaneously in the ultrasonic bath and 16 samples can be centrifuged at the same time. This method can therefore be applied successfully for the multi-element extraction and determination of trace elements in edible oils.

\section{Conclusions}

A new method has been developed for the extraction of trace elements ( $\mathrm{Al}, \mathrm{Ba}, \mathrm{Cd}, \mathrm{Cu}, \mathrm{Fe}$, $\mathrm{Mn}, \mathrm{Mo}, \mathrm{Ni}, \mathrm{Ti}, \mathrm{V}$ and $\mathrm{Zn}$ ) from edible oils using an ultrasound-assisted extraction method employing lipase as an extraction agent at $\mathrm{pH} 3.0$ producing detergentless micro-emulsions. The proposed method was based on the ultrasonic extraction of edible oil by a water phase containing $1 \%$ lipase solution at $\mathrm{pH}$ 3.0. That produces detergentless micro-emulsions enabling trace elements to pass into the water phase. After centrifugation of the emulsions, the oil phase was decanted and the water phase containing the trace elements was subjected to ICP-MS analysis. This new method has several advantages over other methods proposed in the literature and these include simplicity, rapidity, sensitivity, and low cost. In addition, there is no need for the use of toxic chemicals, detergents or concentrated acids. The other advantages of the proposed procedure are that oilbased standards are not required to prepare calibrations graphs and that standard additions or matrix matched standards are not necessary. This proposed method was used to determine trace elements 
(Al, Ba, Cd, Cu, Fe, Mn, Mo, Ni, Ti, V and Zn) from edible oils such as sunflower oil, rapeseed oil, olive oil and salmon oil.

\section{References}

1. E.J. Llorent-Martínez, P. Ortega-Barrales, M.L. Fernández-de Córdova, A. Domínguez-Vidal, A. Ruiz-Medina, Investigation by ICP-MS of trace element levels in vegetable edible oils produced in Spain, Food Chem. 127 (2011) 1257-1262.

2. L.S. Nunes, J.T.P. Barbosa, A.P. Fernandes, V.A. Lemos, W.N.L. Dos Santos, M.G. A. Korn, L.S.G. Teixeira, Multi-element determination of $\mathrm{Cu}, \mathrm{Fe}, \mathrm{Ni}$ and $\mathrm{Zn}$ content in vegetable oils samples by high-resolution continuum source atomic absorption spectrometry and microemulsion sample preparation, Food Chem. 127 (2011) 780783.

3. R.M. De Souza, B. M. Mathias, C. L. P. Da Silveira, R. Q. Aucelio, Inductively coupled plasma optical emission spectrometry for trace multi-element determination in vegetable oils, margarine and butter after stabilization with propan-1-ol and water, Spectrochim. Acta B 60 (2005) $711-715$.

4. A.N. Anthemidis, V. Arvanitidis, J.A. Stratis, On-line emulsion formation and multielement analysis of edible oils by inductively coupled plasma atomic emission spectrometry, Anal. Chim. Acta 537 (2005) 271-278.

5. F. G. Lepri, E. S. Chaves, M. A. Vieira, A. S. Ribeiro, A. J. Curtius, L.C.C. DeOliveira, R. C. DeCampos, Determination of trace elements in vegetable oils and biodiesel by atomic spectrometric techniques - A Review, Appl. Spectrosc. Rev. 46 (2011) 175-206.

6. S. Bağdat Yaşar, E. Köse Baran, M. Alkan, Metal determinations in olive oil, Agricultural and Biological Sciences: Olive Oil - Constituents, Quality, Health Properties and Bioconversions, Edited by Boskou Dimitrios, ISBN 978-953-307-9219. InTech, (2012) 89-108. 
7. A. Angioni, M. Cabitza, M. T. Russo, P. Caboni, Influence of olive cultivars and period of harvest on the contents of $\mathrm{Cu}, \mathrm{Cd}, \mathrm{Pb}$, and $\mathrm{Zn}$ in virgin olive oils, Food Chem. 99 (2006) 525-529.

8. D. Mendil, Ö. D., M. Tüzen, M. Soylak, Investigation of the levels of some element in edible oil samples produced in Turkey by atomic absorption spectrometry, J. Hazard. Mater. 165 (2009) 724-728.

9. I.J. Cindric, M. Zeiner, I. Steffan, Trace elemental characterization of edible oils by ICP-AES and GFAAS, Microchem. J. 85 (2007) 136-139.

10. E.J. Llorent-Martínez, P. Ortega-Barrales, M.L. Fernández-de Córdova, A. Domínguez-Vidal, A. Ruiz-Medina, Investigation by ICP-MS of trace element levels in vegetable edible oils produced in Spain, Food Chem. 127 (2011) 1257-1262.

11. I. Juranovic, P. Breinhoelder, I. Steffan, Determination of trace elements in pumpkin seed oils and pumpkin seeds by ICP-AES, J. Anal. At. Spectrom. 18 (2003) 54-58.

12. F. Lo Coco, L. Ceccon, L. Ciraolo, V. Novelli, Determination of cadmium(II) and zinc(II) in olive oils by derivative potentiometric stripping analysis, Food Control, 14 (2003) 55-59.

13. F.I. De Albuquerque, C.B. Duyck, T.C.O. Fonseca, T.D. Saint'Pierre, Determination of As and Se in crude oil diluted in xylene by inductively coupled plasma mass spectrometry using a dynamic reaction cell for interference correction on ${ }^{80} \mathrm{Se}$, Spectrochim. Acta B 71-72 (2012) 112-116.

14. R. J. Cassella, D. M. Brum, C. E. R. de Paula, C. F. Lima, Extraction induced by emulsion breaking: a novel strategy for the trace metals determination in diesel oil samples by electrothermal atomic absorption Spectrometry, J. Anal. At. Spectrom. 25 (2010) 17041711.

15. Y. M. He, J.J. Chen, Y. Zhou, X.J. Wanga, X.Y. Liu, Extraction induced by emulsion breaking for trace multi-element determination in edible vegetable oils by ICP-MS, Anal. Methods 6 (2014) 5105-5111. 
16. M. Murillo, Z. Benzo, E. Marcano, C. Gomez, A. Garaboto, C. Marin, Determination of copper, iron and nickel in edible oils using emulsified solutions by ICP-AES, J. Anal. At. Spectrom. 14 (1999) 815-820.

17. R.Q. Aucelio, A. Doyle, B. S. Pizzorno, M. L. B. Tristao, R. C. Campos, Electrothermal atomic absorption spectrometric method for the determination of vanadium in diesel and asphaltene prepared as detergentless microemulsions, Microchem. J. 78 (2004) 21- 26.

18. M.N.M. Reyes, R.C. Campos, Graphite furnace atomic absorption spectrometric determination of $\mathrm{Ni}$ and $\mathrm{Pb}$ in diesel and gasoline samples stabilized as microemulsion using conventional and permanent modifiers, Spectrochim. Acta B 60 (2005) 615- 624.

19. J. C. Cypriano, M.A.C. Matos, R. C. Matos, Ultrasound-assisted treatment of palm oil samples for the determination of copper and lead by stripping chronopotentiometry, Microchem. J. 90 (2008) 26-30.

20. D. Bakircioglu, Y. Bakircioglu Kurtulus, S.Yurtsever, Comparison of extraction induced by emulsion breaking, ultrasonic extraction and wet digestion procedures for determination of metals in edible oil samples in Turkey using ICP-OES, Food Chem. 138 (2013) 770-775.

21. P. Moreno, M.A. Quijano, A.M. Gutiérrez, M.C. Pérez-Conde, C. Cámara, Fractionation studies of selenium compounds from oysters, and their determination by high-performance liquid chromatography coupled to inductively coupled plasma mass spectrometry, J. Anal. Atom. Spectrom., 16 (2001) 1044-1050.

22. C. Pena-Fartal, A. Moreda-Pineiro, A. Bermejo-Barrera, P. Bermejo-Barrera, H. PinochetCancino, I.Gregori-Henriquez, Ultrasound bath-assisted enzymatic hydrolysis procedures as sample pretreatment for the multielement determination in mussels by inductively coupled plasma atomic emission spectrometry, Anal. Chem. 76 (2004), 3541-3547.

23. G. Schwedt, K.D. Neumann, Application of enzymes for metal speciation analysis of iron and manganese in foodstuffs, Z. Lebensm. Unters. Forsch.194 (1992), 152-155. 
24. F. Mellano, M. Bujalance, I. Giráldez, P. Ruiz-Azcona, D. Sánchez-Rodas, E. Morales, Determination of selenomethionine and seleno-methyl-selenocysteine in biota by ultrasonicassisted enzymatic digestion and multi-shot stir bar sorptive extraction-thermal desorptiongas chromatography-mass spectrometry, J. Chromatogr. A 1300 (2013) 151-158.

\section{Figure Captions}

Figure 1. The effect of $\mathrm{pH}$

Figure 2. The effect of the volume of $1 \%$ lipase 
Table 1. The results of trace elements for the certified material (EnviroMAT HU-1 Used oil).

\begin{tabular}{|c|c|c|c|c|c|}
\hline \multirow[b]{2}{*}{ Element } & & & & \multicolumn{2}{|c|}{ Reference Values } \\
\hline & $\begin{array}{l}\text { This Method } \\
\text { Found, } \mu \mathrm{g} \mathrm{g}^{-1} \\
\bar{x} \pm s(\mathrm{~N}=3)\end{array}$ & $\begin{array}{l}\text { Comparison } \\
\text { Method, } \mu \mathrm{g} \mathrm{g}^{-1} \\
\bar{x} \pm s(\mathrm{~N}=3)\end{array}$ & $t_{d}=\frac{\left|\bar{x}_{1}-\bar{x}_{2}\right|}{S_{b} \sqrt{\frac{N_{1}+N_{2}}{N_{1} \cdot N_{2}}}}$ & $\begin{array}{l}\text { Consensus } \\
\text { Value } \\
\mu \mathrm{g} \mathrm{g}^{-1}\end{array}$ & $\begin{array}{c}\text { Confidence } \\
\text { Interval } 95 \% \\
\mu \mathrm{g} \mathrm{g}^{-1}\end{array}$ \\
\hline $\mathrm{Al}$ & $14.3 \pm 2.8$ & $18.3 \pm 1.2$ & -2.27 & 14 & $11-17$ \\
\hline $\mathrm{Ba}$ & $8.09 \pm 0.89$ & $7.43 \pm 0.60$ & 1.07 & 9 & $8.5-9.5$ \\
\hline $\mathrm{Cd}$ & $14.3 \pm 0.7$ & $16.2 \pm 1.4$ & -2.10 & 15 & $14-16$ \\
\hline $\mathrm{Cu}$ & $3033 \pm 121$ & $2869 \pm 172$ & 1.35 & 3132 & $2906-3358$ \\
\hline $\mathrm{Fe}$ & $54.4 \pm 7.2$ & $70.3 \pm 4.6$ & -3.22 & 59 & $53-65$ \\
\hline Mn & $18.2 \pm 0.7$ & $16.4 \pm 1.1$ & 2.39 & 18 & $17-19$ \\
\hline Mo & $11.6 \pm 0.4$ & $8.33 \pm 0.76$ & 6.59 & 11 & $10-12$ \\
\hline $\mathrm{Ni}$ & $39.5 \pm 2.0$ & $40.1 \pm 2.7$ & -0.31 & 45 & $42-48$ \\
\hline $\mathrm{Ti}$ & $9.57 \pm 1.8$ & $12.7 \pm 1.0$ & -2.63 & 9 & $7-11$ \\
\hline V & $7.10 \pm 0.42$ & $7.25 \pm 0.47$ & -0.41 & 7 & $6.5-7.5$ \\
\hline $\mathrm{Zn}$ & $15.1 \pm 1.1$ & $14.2 \pm 2.1$ & 0.66 & 16 & $14-18$ \\
\hline
\end{tabular}

Where $\bar{x}_{1}$ and $\bar{x}_{2}$ represent experimental means and $\mathrm{s}_{1}$ and $\mathrm{s}_{2}$ represent experimental standard deviations obtained by the proposed method and a comparison method successively. The critical value of $\mathrm{t}$ for 4 degrees of freedom is 2.78 at the $95 \%$ confidence interval. 
Table 2. The results of trace elements for different edible oils $\left(\mu \mathrm{g} \mathrm{kg}^{-1}, \mathrm{n}=3\right)$.

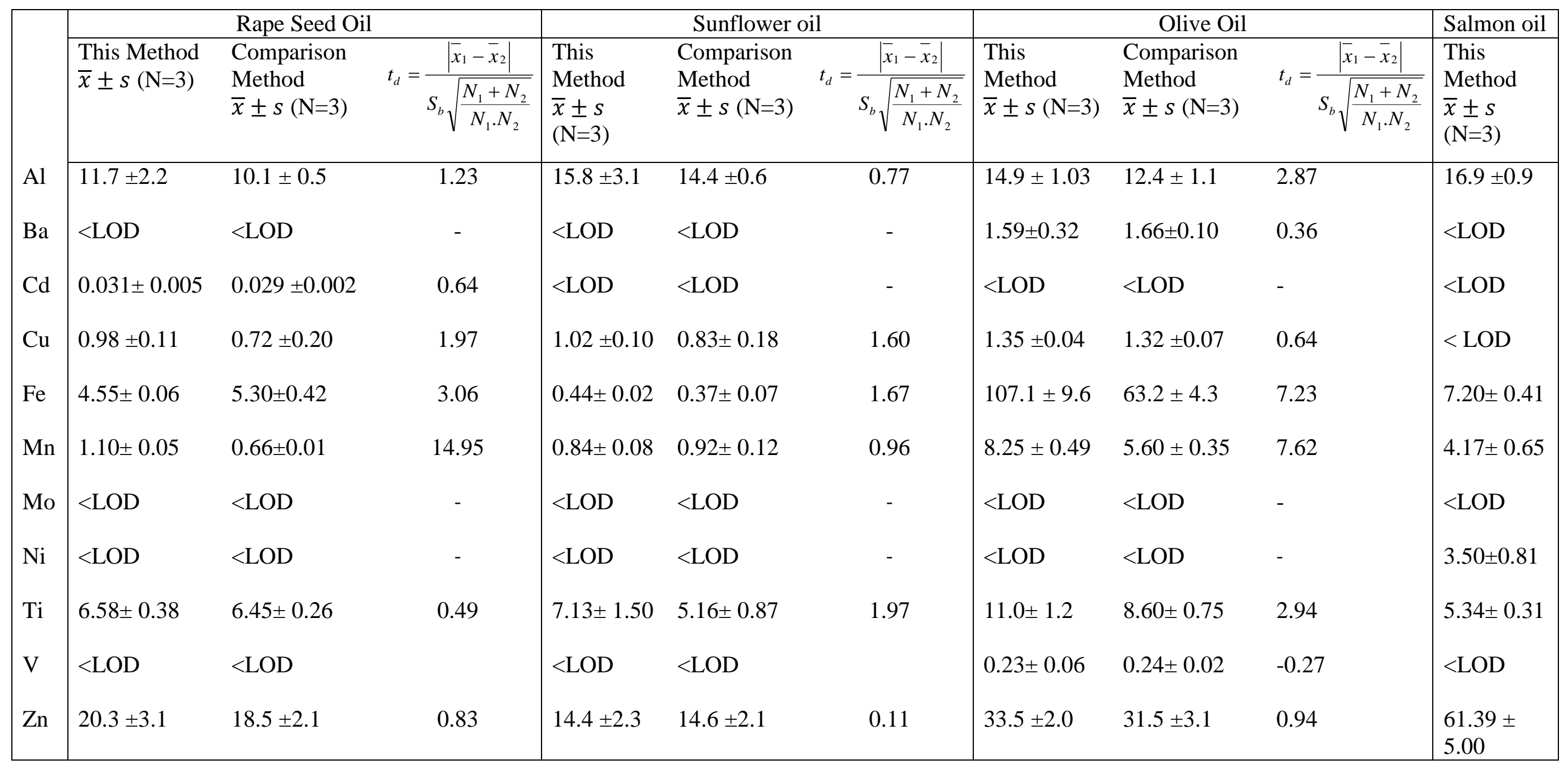

Where $\bar{x}_{1}$ and $\bar{x}_{2}$ represent experimental means and $\mathrm{s}_{1}$ and $\mathrm{s}_{2}$ represent experimental standard deviations obtained by the proposed method and a comparison method successively. The critical value of $\mathrm{t}$ for 4 degrees of freedom is 2.78 at the $95 \%$ confidence interval. 
Table 3. The comparison of the sample pre-treatment methods used to determine trace elements from oil samples

\begin{tabular}{|c|c|c|c|c|c|c|}
\hline Method & & Elements & Sample & $\begin{array}{l}\text { Spectroscopic } \\
\text { Technique }\end{array}$ & LOD & Ref. \\
\hline Dilution & $\begin{array}{l}20 \text { fold } \\
\text { dilution in } \\
\text { Xylene }\end{array}$ & As, Se & Crude oil & ICP-MS & $\begin{array}{l}0.04(\mathrm{As}) 0.1(\mathrm{Se}) \\
\left(\mu \mathrm{gg}^{-1}\right)\end{array}$ & [12] \\
\hline $\begin{array}{l}\text { Emulsion } \\
\text { breaking } \\
(\text { EIEB) }\end{array}$ & $\begin{array}{l}7 \% \mathrm{w} / \mathrm{v} \\
\text { Triton X- } \\
114 \text { and } \\
10 \% \mathrm{v} / \mathrm{v} \\
\mathrm{HNO}_{3}\end{array}$ & $\begin{array}{l}\mathrm{Cu}, \mathrm{Fe}, \\
\mathrm{Ni} \text { and } \\
\mathrm{Pb}\end{array}$ & Diesel oil & ETAAS & $\begin{array}{l}114(\mathrm{Cu}), 183(\mathrm{Fe}) \\
145(\mathrm{Ni}) 294(\mathrm{~Pb}) \\
\mathrm{ng} \mathrm{L}^{-1}\end{array}$ & [13] \\
\hline $\begin{array}{l}\text { Emulsion } \\
\text { breaking } \\
\text { (EIEB) }\end{array}$ & $\begin{array}{l}12 \% \mathrm{w} / \mathrm{v} \\
\text { Triton X- } \\
114 \text { and } \\
20 \% \mathrm{v} / \mathrm{v} \\
\mathrm{HNO}_{3}\end{array}$ & $\begin{array}{l}\mathrm{Mg}, \mathrm{Mn}, \\
\mathrm{Fe}, \\
\mathrm{Zn}, \mathrm{Ag}, \\
\mathrm{Ba}, \mathrm{Pb} \\
\text { and } \mathrm{Cr}\end{array}$ & $\begin{array}{l}\text { Edible } \\
\text { oils }\end{array}$ & ICP-MS & $\begin{array}{l}0.093(\mathrm{Mg}), 0.052 \\
(\mathrm{Mn}), 0.271(\mathrm{Fe}) \\
0.177(\mathrm{Zn}) 0.007 \\
(\mathrm{Ag}), 0.009(\mathrm{Ba}) \\
0.004(\mathrm{~Pb}), 0.033 \\
(\mathrm{Cr}) \mu \mathrm{g} \mathrm{L}^{-1}\end{array}$ & [14] \\
\hline $\begin{array}{l}\text { Direct } \\
\text { analysis of } \\
\text { detergent } \\
\text { emulsions }\end{array}$ & $\begin{array}{l}\text { Detergent } \\
\text { emulsions } \\
\text { with Triton } \\
\text { X-100 }\end{array}$ & $\begin{array}{l}\mathrm{Ag}, \mathrm{Al}, \\
\mathrm{B}, \mathrm{Ba}, \\
\mathrm{Bi}, \mathrm{Ca}, \\
\mathrm{Cd}, \mathrm{Co}, \\
\mathrm{Cr}, \mathrm{Cu}, \\
\mathrm{Fe}, \mathrm{Ga}, \\
\mathrm{In}, \mathrm{Mg}, \\
\mathrm{Mn}, \mathrm{Ni} \\
\mathrm{Pb}, \mathrm{Tl}\end{array}$ & $\begin{array}{l}\text { Edible } \\
\text { oils }\end{array}$ & ICP-OES & NA & [4] \\
\hline $\begin{array}{l}\text { Direct } \\
\text { analysis of } \\
\text { detergent } \\
\text { emulsions }\end{array}$ & $\begin{array}{l}\text { Detergent } \\
\text { emulsions } \\
\text { with Triton } \\
\text { X-100 }\end{array}$ & $\begin{array}{l}\mathrm{Cu}, \mathrm{Fe}, \\
\mathrm{Ni}\end{array}$ & $\begin{array}{l}\text { Edible } \\
\text { oils }\end{array}$ & ICP-OES & NA & [15] \\
\hline $\begin{array}{l}\text { Alcoholic } \\
\text { dispersions }\end{array}$ & $\begin{array}{l}\text { Propan-1- } \\
\text { ol/water } \\
\text { (70:30 w/w) } \\
\text { for Soy and } \\
\text { olive oils, } \\
\text { Propan-1ol/ } \\
\text { water/xylene } \\
\text { (75:25:5 } \\
\text { w/w/w) for } \\
\text { butter and } \\
\text { margarine }\end{array}$ & $\begin{array}{l}\mathrm{Cd}, \mathrm{Co}, \\
\mathrm{Cr}, \mathrm{Cu}, \\
\mathrm{Ni} \text { and } \\
\mathrm{Mn}\end{array}$ & $\begin{array}{l}\text { Vegetable } \\
\text { oils, } \\
\text { margarine } \\
\text { and butter }\end{array}$ & ICP-OES & $\begin{array}{l}7.8(\mathrm{Ni}), 10(\mathrm{Co}), 5 \\
(\mathrm{Cd}), 0.9(\mathrm{Mn}), 3 \\
(\mathrm{Cu}), 2.8(\mathrm{Cr}) \\
\left(\mu \mathrm{gg}^{-1}\right)\end{array}$ & [3] \\
\hline $\begin{array}{l}\text { Alcoholic } \\
\text { dispersions }\end{array}$ & $\begin{array}{l}\text { Propan-1-ol } \\
\text { and } 6 \mathrm{M} \\
\text { nitric acid }\end{array}$ & V & $\begin{array}{l}\text { Diesel } \\
\text { and } \\
\text { asphaltene }\end{array}$ & ETAAS & $\begin{array}{l}5 \mu \mathrm{g} \mathrm{L}^{-1} \text { (diesel } \\
\text { samples) and } 4 \mu \mathrm{g} \\
\mathrm{L}^{-1} \text { (asphaltene } \\
\text { samples) }\end{array}$ & [16] \\
\hline $\begin{array}{l}\text { Alcoholic } \\
\text { dispersions }\end{array}$ & $\begin{array}{l}6.5 \mathrm{ml} \text { of } \\
\text { propan-1-ol } \\
\text { and } 0.1 \mathrm{ml} \\
\text { of } 50 \% \\
\text { vol/vol }\end{array}$ & $\begin{array}{l}\mathrm{Ni} \text { and } \\
\mathrm{Pb}\end{array}$ & $\begin{array}{l}\text { Diesel } \\
\text { and } \\
\text { gasoline }\end{array}$ & ETAAS & $\begin{array}{l}4.5(\mathrm{Ni}) 3.6(\mathrm{~Pb}) \\
\mu \mathrm{g} \mathrm{L}^{-1}\end{array}$ & [17] \\
\hline
\end{tabular}




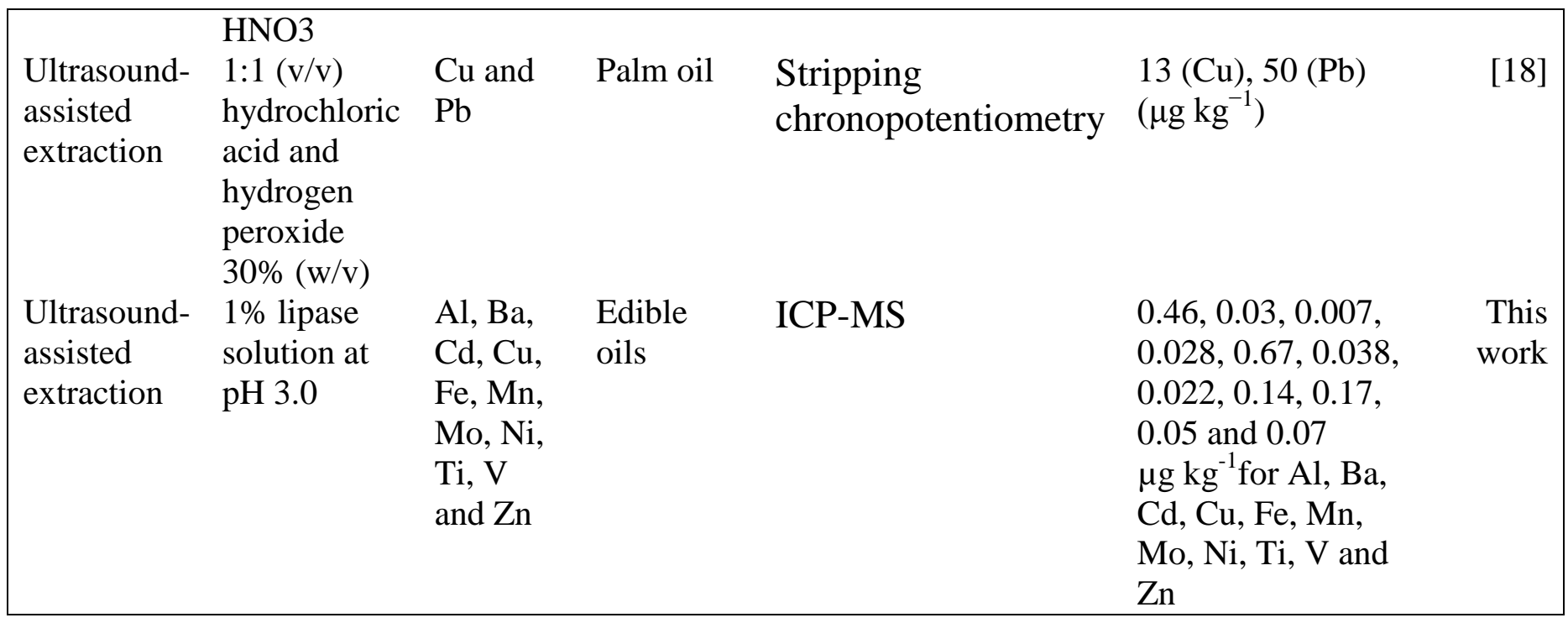

